\title{
Correction to: Combination of ELISA screening and seroneutralisation tests to expedite Zika virus seroprevalence studies
}

Elif Nurtop ${ }^{1 *}$, Paola Mariela Saba Villarroel ${ }^{1,2}$, Boris Pastorino $^{1}$, Laetitia Ninove ${ }^{1}$, Jan Felix Drexler ${ }^{3}$, Yelin Roca ${ }^{2}$, Bouba Gake ${ }^{1,4}$, Audrey Dubot-Peres ${ }^{1}$, Gilda Grard ${ }^{1,5}$, Christophe Peyrefitte ${ }^{1,5}$, Stéphane Priet ${ }^{1}$, Xavier de Lamballerie ${ }^{1}$ and Pierre Gallian ${ }^{1,6}$

\section{Correction to: Virol J}

\section{https://doi.org/10.1186/s12985-018-1105-5}

In the original publication of this article [1],

Table 1 has some errors. The correct one is below:

Table 1 Comparison of VNT and PRNT assays for a panel of 142 samples

\begin{tabular}{|c|c|c|c|c|}
\hline \multirow[t]{2}{*}{ VNT } & \multicolumn{2}{|l|}{ PRNT50 } & \multicolumn{2}{|l|}{ PRNT90 } \\
\hline & Positive (titre $\geq 10$ ) & Negative (titre < 10) & Positive (titre $\geq 10$ ) & Negative (titre $<10$ ) \\
\hline Positive (titre $\geq 40$ ) & 51 & 1 & 51 & 1 \\
\hline Negative (titre < 40) & 9 & 81 & 1 & 89 \\
\hline $\begin{array}{l}\text { Sensitivity of VNT } \\
(95 \% \mathrm{Cl})\end{array}$ & $\begin{array}{l}85 \%(51 / 60) \\
(72.9-92.4 \%)\end{array}$ & & $\begin{array}{l}98.8 \%(51 / 52) \\
(88.4-99.9 \%)\end{array}$ & \\
\hline $\begin{array}{l}\text { Specificity of VNT } \\
(95 \% \mathrm{Cl})\end{array}$ & $\begin{array}{l}98.7 \%(81 / 82) \\
(92.4-99.9 \%)\end{array}$ & & $\begin{array}{l}98.8 \%(89 / 90) \\
(93.1-99.9 \%)\end{array}$ & \\
\hline
\end{tabular}

The publisher apologizes to the readers and authors for the inconvenience.

The original publication has been corrected.

\begin{abstract}
Author details
'Unité des Virus Émergents (UVE: Aix-Marseille Univ - IRD 190 - Inserm 1207- IHU Méditerranée Infection), Marseille, France. ²Virología II, Centro Nacional de Enfermedades Tropicales (CENETROP), Santa Cruz de la Sierra, Bolivia. ${ }^{3}$ Institute of Virology, Charité-Universitätsmedizin Berlin, Berlin, Germany. ${ }^{4}$ Centre Pasteur du Cameroun, Yaoundé, Cameroon. ${ }^{5}$ National Reference Centre for Arboviruses, French Armed Forces Biomedical Research Institute, Marseille, France. ${ }^{6}$ Laboratoire de Virologie, Établissement Français du Sang Alpes Méditerranée (EFS), Marseille, France.
\end{abstract}

Received: 4 January 2019 Accepted: 8 January 2019

Published online: 18 January 2019

\section{Reference}

1. Nurtop, et al. Combination of ELISA screening and seroneutralisation tests to expedite Zika virus seroprevalence studies. Virol J. 2018;15:192. https:// doi.org/10.1186/s12985-018-1105-5.

\footnotetext{
*Correspondence: enurtop@gmail.com

'Unité des Virus Émergents (UVE: Aix-Marseille Univ - IRD 190 - Inserm

1207- IHU Méditerranée Infection), Marseille, France

Full list of author information is available at the end of the article
}

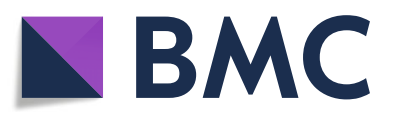

(c) The Author(s). 2019 Open Access This article is distributed under the terms of the Creative Commons Attribution 4.0 International License (http://creativecommons.org/licenses/by/4.0/), which permits unrestricted use, distribution, and reproduction in any medium, provided you give appropriate credit to the original author(s) and the source, provide a link to the Creative Commons license, and indicate if changes were made. The Creative Commons Public Domain Dedication waiver (http://creativecommons.org/publicdomain/zero/1.0/) applies to the data made available in this article, unless otherwise stated. 